\title{
Measurement of protein in nearshore marine sediments
}

\author{
Lawrence M. Mayer, Linda L. Schick \& Frank W. Setchell \\ Department of Geological Sciences and Program in Oceanography, Ira C. Darling Center, University of Maine at Orono, \\ Walpole, Maine 04573, USA
}

\begin{abstract}
Proteinaceous material in marine sediments which is available to proteolytic hydrolysis has been measured using a new method. This technique utilizes Coomassie Blue dye binding, which has the advantage of being sensitive only to larger polypeptides. Substantial interferences from other sedimentary organic substances are overcome by using a standard additions approach in conjunction with enzymatic digestion of the protein. Although tedious, the technique provides acceptable precision and accuracy. Measurements of protein in surficial nearshore sediments of the Gulf of Maine and St. Croix yield values ranging from 0.1 to $2.2 \mathrm{mg} \mathrm{g}^{-1}$, which account for a minor fraction of total nitrogen or acid-hydrolyzable amino acids. Protein decreases downcore at a faster rate than either of these 2 indicators of nitrogenous material, indicating the greater lability of the truly proteinaceous material. Biomass comprises a minor portion of the measured protein.
\end{abstract}

\section{INTRODUCTION}

The study of benthic metabolism has long been hindered by the lack of chemical measurements with which to assess the nutritional value of sedimentary organic matter. Numerous analytical techniques exist to estimate total amounts of organic matter (e.g. Mills \& Quinn 1978, Hedges \& Stern 1984) or any of a variety of organic compound classes, such as amino acids or carbohydrates (e.g. Mopper 1977, Carter \& Mitterer 1978). However, it is difficult to estimate that fraction of any of these classes actually available to benthic heterotrophs. This problem derives largely from the fact that the bulk of sedimentary organic matter, and indeed probably most of any particular compound class of organic matter, is bound into refractory, geopolymeric materials that are of little biological relevance on short $(<1$ yr) time scales (van Es 1982, Mayer et al. 1985).

One class of organic materiais of particular importance in benthic ecology is the nitrogenous compounds (Tenore 1983). The subclass of interest in this regard is the proteins, those larger polymers of amino acids that form the bulk of nitrogen in fresh, labile organic inputs to sediments. Estimation of sedimentary protein concentrations to date has relied in all instances on the determination of subunits of proteins, i.e. either amino acids or peptide bonds (e.g. Buchanan \& Longbottom
1970, Greenfield et al. 1970, Hatcher 1978, Rice 1982, Meyer-Reil 1983, Simon \& Jones 1983). However, these analyses are all subject to the problem that geopolymerized oligopeptides or individual amino acids may have dominated the results. Analyses of total hydrolyzable amino acids are vulnerable to the same criticism.

One useful solution to this problem would be to use an analytical technique which is sensitive only to larger polypeptides, which more closely resemble the true proteins to be found in fresh detritus. In addition, such a technique should measure only those polypeptides that are not so bound by humic substances that they are unavailable to enzymatic attack. We present here an analytical scheme that shows promise in achieving these goals.

Our technique is based on the reaction of Coomassie Blue dye ( $\mathrm{CB}$ ) with proteins (Bradford 1976). $\mathrm{CB}$ dye has the advantage of being sensitive only to larger polypeptides, with reported minimum polymer sizes of 10 to 25 amino acid residues (Sedmak \& Grossberg 1977, Righetti \& Chillemi 1978). Our early studies in using the Setchell (1981) modification of this method to examine protein in sediments showed that the dye is also sensitive to the colored humic materials in sediment extracts. We verified this interference by finding that $\mathrm{CB}$ dye reacts intensely with commercial humic acid (Aldrich) and reagent tannic acid (Fisher), each of which contains essentially no protein. As a means of 
separating that portion of the reaction due to proteinaceous material from that due to humic substances, we have developed an enzymatic digestion of the sediment extract which hydrolyzes the protein and thus renders it unreactive to $C B$. The difference between the hydrolyzed and unhydrolyzed material thus represents protein in sediment available to enzymatic attack.

\section{ANALYTICAL CONSIDERATIONS}

\section{Analytical method}

The method with which we have found most success is illustrated in Fig. 1. A sample of $0.2 \mathrm{~g}$ of sediment, which has been preserved either frozen or freezedried, is extracted with $6 \mathrm{ml}$ of $0.1 \mathrm{~N} \mathrm{NaOH}$ for $2 \mathrm{~h}$ at $60^{\circ} \mathrm{C}$, agitating the sample occasionally to promote mixing. Drying of the sediment at room temperature or above has been found to result in reduced yields of analyzed protein. Longer extraction times have also been found to result in decreased yields, and additional extractions do not yield any further protein release from the sediment. The suspension is cooled and centrifuged, and $5 \mathrm{ml}$ of the supernatant extract is removed. To this extract is added $0.1 \mathrm{ml}$ of $2.5 \mathrm{~N} \mathrm{HCl}$, and then the $\mathrm{pH}$ is carefully adjusted to $\mathrm{pH} 7.5$ to 8.5 with dilute $\mathrm{HCl}$, recording the volume added. It is critical to prevent the pH from falling below 6; below this $\mathrm{pH}$, flocs containing some of the protein are often formed. Five $1 \mathrm{ml}$ aliquots of the neutralized extract are then placed into 5 small plastic tubes. Glassware should be avoided, as it results in adsorptive losses of protein. To the first tube is added $0.1 \mathrm{ml}$ of a $100 \mu \mathrm{g}$ $\mathrm{ml}^{-1}$ solution of a bacterial protease (Sigma Pronase $\mathrm{E}_{\text {, }}$ \#P5147) and $0.1 \mathrm{ml}$ of a $125 \mu \mathrm{g} \mathrm{ml} \mathrm{m}^{-1}$ solution of a fungal protease (Sigma Proteinase K, \#P0390). The second tube receives $0.2 \mathrm{ml}$ of distilled water. The third, fourth, and fifth tubes receive standard additions spikes of $0.2 \mathrm{ml}$ of 200,400 , and $600 \mu \mathrm{g} \mathrm{ml} \mathrm{m}^{-1}$ solutions of casein (Fisher), respectively. All 5 tubes are left to sit overnight, during which time the protease mixture hydrolyzes most of the natural protein in the first tube. On the following day, all the tubes are heated at $60^{\circ} \mathrm{C}$ for $1 \mathrm{~h}$, followed by $80^{\circ} \mathrm{C}$ for another hour. These steps serve to finish the hydrolysis of both the sedimentary protein and the added proteases. The heating steps do

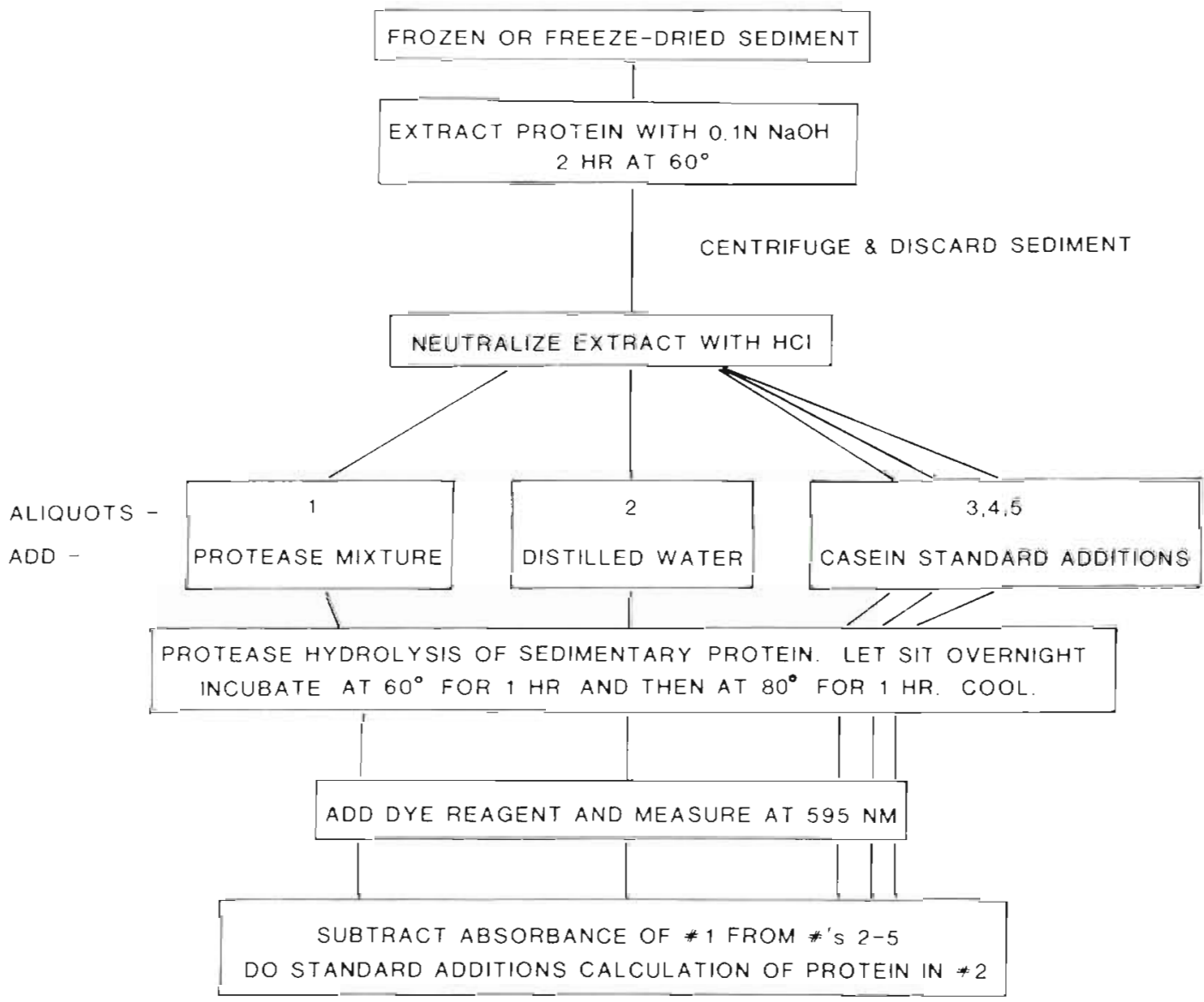

Fig. 1. Flow chart of protein analytical scheme 
not, however, decrease the reactivity of the extracted proteins to the $C B$ dye. After cooling in a water bath, the samples are analyzed by adding $0.3 \mathrm{ml}$ sample to $3 \mathrm{ml}$ of a CB dye solution (best results are obtained with the dye-reagent \#1 of Read \& Northcote 1981 . using Serva Blue G-250; the stock solution is made by dissolving $100 \mathrm{mg}$ dye in $200 \mathrm{ml}$ phosphoric acid and $100 \mathrm{ml}$ ethanol, with the working dye reagent consisting of $30 \mathrm{ml}$ dye stock mixed with $80 \mathrm{ml}$ phosphoric acid and $37.5 \mathrm{ml}$ ethanol, brought to 11 with distilled water and filtered through a Whatman \#1 filter). The absorbance is measured at $595 \mathrm{~nm}$ in a $1 \mathrm{~cm}$ glass cell. The absorbance of the first tube is considered the protein-free blank value, representing the reaction of the dye with the humic material in the extract. The absorbance of the first tube is subtracted from the absorbances of the remaining 4 tubes, which are used in a standard additions calculation of the protein content of the second tube.

This analytical scheme is quite time-consuming Replication of samples to quadruplicates before $\mathrm{NaOH}$ extraction and further to triplicates just before spectrophotometric analysis results in 60 spectrophotometric numbers per protein value obtained. One experienced analyst typically produces about 15 data points per week. Replication might be reduced with samples containing relatively high levels of protein in sediments with low humic content, such as silty or sandy surficial sediments in productive areas.

\section{Recovery efficiency}

The recovery of protein from sediments has been estimated by adding proteins, in the form of either casein or a $\mathrm{NaOH}$ extract of a phytoplankton culture, to sediments before the sedimentary $\mathrm{NaOH}$ extraction step. Recoveries range from 70 to $90 \%$, and average about $80 \%$. It is therefore likely that our measure of protein is low by 10 to $30 \%$. Due to the probability that different proteins will have different recovery efficiencies, as well as the fact that we cannot determine the recovery efficiency for natural sedimentary protein, we do not apply any correction factor for incomplete recovery to our results.

\section{Precision}

The precision of this analysis is dependent upon the magnitude of the humic interference relative to the protein signal. Humic material interferes in both an additive and a multiplicative manner (sensu O'Haver 1976). Typical precision for surficial (top several $\mathrm{cm}$ ) sediments is \pm 15 to $20 \%$, as a coefficient of variation.
Deeper sediments (tens of $\mathrm{cm}$ ) generally contain less protein and greater concentrations of interfering humic substances. Analyses of these samples can yield values approaching the detection limit. This limit, defined as 3 times the standard deviation of the protease-digested aliquot, varies among samples. Downcore detection limits typically range from 0.05 to $0.5 \mathrm{mg}$ protein $\mathrm{g}^{-1}$, and so care needs to be taken that only samples with an adequate signal-to-noise ratio are accepted. Near the detection limit the precision can be as poor as $\pm 70 \%$ (coefficient of variation), though \pm 20 to $30 \%$ is more typical for downcore samples.

\section{Variability of dye response to different proteins}

One of the well-known problems with the CB assay is its variable reactivity with different proteins (Bradford 1976, Bearden 1978, Pollard et al. 1978). This problem is overcome in our analysis by 3 factors. First, the dye recipe of Read \& Northcote (1981) shows less variability of reactivity to different proteins than other dye formulations. Second, we have found that the humic interference has the positive benefit of further reducing variability. This finding is evidenced by similar standard additions slopes for bovine gamma globulin and casein additions in sediment extracts; these 2 proteins show differing reactivities when assayed in distilled water solution.

Third, variable reactivity of different proteins is reduced by the fact that complex mixtures of proteins are being measured. We have assessed the variability of protein mixtures of different marine origins to $\mathrm{CB}$ analysis, calibrating this reactivity by determination of the protein contents of semi-purified extracts from different sources using the Biuret method and total nitrogen analysis. Five potential sources of protein were examined - 2 seaweeds (Fucus vesiculosis and Ascophyllum nodosum), a mixed phytoplankton culture (dominated by Thalassiosira pseudonana and Dunaliella tertiolecta), a clam (Mya arenaria), and a culture of sedimentary bacteria grown by inoculating 61 of filtered seawater with ca $0.1 \mathrm{~g}$ of mudflat sediment which was then spiked with an acid hydrolyzate of casein, grown in the dark for $3 d$, and harvested (SEM examination showed only mixed bacteria in the resultant culture). Each of these materials was extracted with $0.1 \mathrm{~N} \mathrm{NaOH}$ at $60^{\circ} \mathrm{C}$. The extracts from the seaweeds were titrated with $\mathrm{HCl}$ to precipitate polysaccharides, which may have removed some protein. All protein extracts were then twice precipitated by addition of $15 \%$ trichloroacetic acid and redissolved in $0.1 \mathrm{~N} \mathrm{NaOH}$ to result in a semi-purified protein extract, which was adjusted to $\mathrm{pH}<7$ with $\mathrm{HCl}$. The resultant solutions were then assayed for 
Table 1 Total $N$ vs Protein- $N$ in TCA extracts. $\Sigma N$ is total nitrogen from persulfate oxidation of semi-purified protein extracts. CB protein $N$ and Biuret protein ir are calculated from protein values in bovine $\gamma$-globulin equivalents using a factor of 6.25 after correction for dilutions

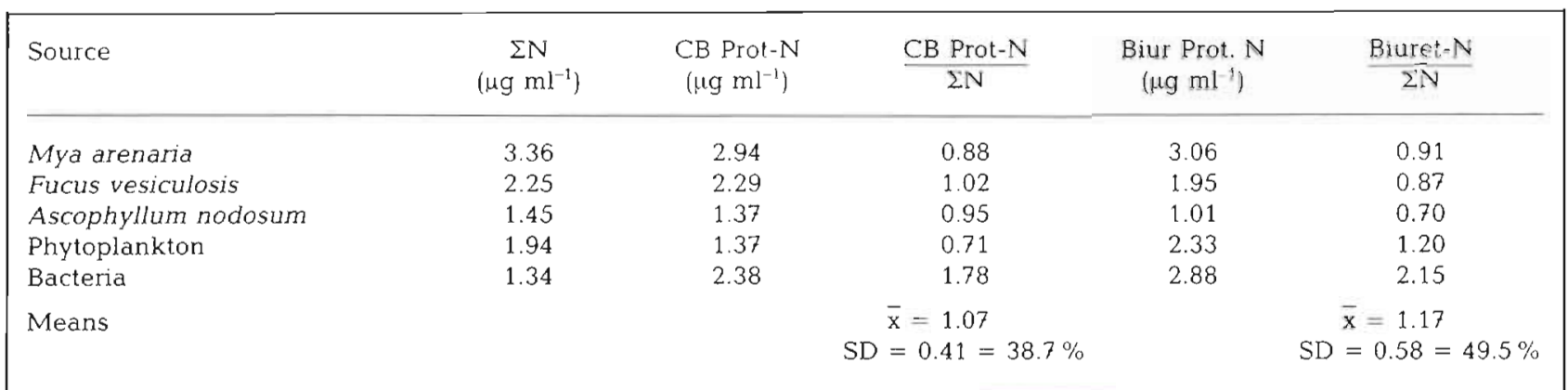

protein with the reagents and recipe from Bio Rad Laboratories, using bovine gamma globulin as a standard. These solutions were also analyzed for protein with the Biuret reagent $(2.0 \mathrm{ml}$ sample: $5.0 \mathrm{ml}$ Biuret reagent) and assayed for total nitrogen by the method of D'Elia et al. (1978).

The results of this intercalibration (Table 1) indicate that the average reactivity of the $C B$ analysis to protein mixtures from the 5 different sources is similar to both the Biuret method and the total nitrogen analysis. Large deviations from the total nitrogen analysis are found for bacterial protein, using both the $C B$ and the Biuret method. The CB technique shows slightly less variability than the Biuret method. The average ratio of protein nitrogen to total nitrogen of about 1 for both methods indicates that bovine gamma globulin, and hence casein (see above), acts as a suitable standard for sedimentary protein.

Table 2. CB reactivity of a variety of polypeptides and proteins which vary with respect to polymer length and composition. Absorbances in all cases refer to $100 \mu \mathrm{g} \mathrm{m}^{-1}$ peptide solutions

\begin{tabular}{|c|c|c|c|}
\hline $\begin{array}{l}\text { Number of } \\
\text { residues }\end{array}$ & Name & Composition & Absorbance \\
\hline 4 & & VAL-ALA-ALA-PHE & 0 \\
\hline 4 & Substance N Fragment 1-4 & ARG-PRO-LYS-PRO & 0 \\
\hline 5 & Proctolin & ARG-TYR-LEU-PRO-THR & 0 \\
\hline 5 & Leucine enkephalin & TYR-GLY-GLY-PI IE-LEU & 0 \\
\hline 6 & Neurotensin Fragment 8-13 & ARG-ARG-PRO-TYR-ILE-LEU & 0.294 \\
\hline 7 & Kemptide & LEU-ARG-ARG-ALA-SER-LEU-GLY & 0 \\
\hline 8 & & VAL-HIS-LEL-THR-PRO-VAL-GLU-LYS & 0 \\
\hline 8 & Angiotensin II & ASP-ARG-VAL-TYR-ILE-HIS-PRO-PHE & 0.073 \\
\hline 9 & Bradykinin & ARG-PRO-PRO-GLY-PHE-SER-PRO-PHE-ARG & 0.077 \\
\hline 10 & Angiotensin I & ASP-ARG-VAL-TYR-ILE-HIS-PRO-PHE-HIS-LEU & 0.506 \\
\hline 11 & Ranatensin & GLU-VAL-PRO-GLN-TRP-ALA-VAL-GLY-HIS-PHE-MET- $\mathrm{NH}_{2}$ & 0 \\
\hline 13 & Dynorphin A Fragment $1-13$ & $\begin{array}{l}\text { TYR-GLY-GLY-PHE-LEU-ARG-ARG-ILE-ARG-PRO-LYS-LEU- } \\
\text { LYS }\end{array}$ & 0.939 \\
\hline 13 & {$[$ Phe" $]$-neurotensin } & $\begin{array}{l}\text { GLU-LEU-TYR-GLU-ASN-LYS-PRO-ARG-ARG-PRO-PHE-ILE- } \\
\text { LEU }\end{array}$ & 0.522 \\
\hline 14 & Porcine angiotensin $1-14$ & $\begin{array}{l}\text { ASP-ARG-VAL-TYR-ILE-HIS-PRO-PHE-HIS-LEU-LEU-VAL- } \\
\text { TYR-SER }\end{array}$ & 0.815 \\
\hline 17 & Dynorphin A & $\begin{array}{l}\text { TYR-GLY-GLY-PHE-LEU-ARG-ARG-ILE-ARG-PRO-LYS-LEU- } \\
\text { LYS-TRP-ASP-ASN-GLN }\end{array}$ & 1.979 \\
\hline 17 & Tyr-fibrinopeptide A & $\begin{array}{l}\text { TYR-ALA-ASP-SER-GLY-GLU-GLY-ASP-PHE-LEU-ALA-GLU- } \\
\text { GLY-GLY-GLY-VAL-ARG }\end{array}$ & 0 \\
\hline 21 & Bovine insulin, Chain A & $\begin{array}{l}\text { GLY-ILE-VAL-GLU-GLN-CYS-CYS-THR-SER-ILE-CYS-SER- } \\
\text { LEU-TYR-GLN-LEU-GLU-ASN-TYR-CYS-ASN }\end{array}$ & 0 \\
\hline 30 & Bovine insulin, Chain B & $\begin{array}{l}\text { PHE-VAL-ASN-GLN-HIS-LEU-CYS-GLY-SER-HIS-LEU-VAL- } \\
\text { GLU-ALA-LEU-TYR-LEU-VAL-CYS-GLY-GLU-ARG-GLY-PHE- } \\
\text { PHE-TYR-THR-PRO-LYS-THR }\end{array}$ & 0.644 \\
\hline 241 & Chymotrypsin & & 0.480 \\
\hline 223 & Trypsin & & 0.350 \\
\hline 209 & Casein & & 0.537 \\
\hline ca 1250 & Bovine gamma globulin & & 0.453 \\
\hline
\end{tabular}




\section{Minimum polypeptide size}

An important consideration in the interpretation of CB dye binding assays in sediments is the size of the polymers being detected. We examined this question by determining the $\mathrm{CB}$ reactivity of a variety of polypeptides of varying lengths and amino acid composition. The peptides (Table 2 ; obtained from Sigma) were assayed using a ratio of $2.0 \mathrm{ml}$ of the Read \& Northcote (1981) dye solution to $0.2 \mathrm{ml}$ of $100 \mu \mathrm{g} \mathrm{ml}^{-1}$ peptide solution. The results of this test (Table 2 ; also tabulated are several proteins) show no peptides of less than 6 amino acid residues exhibiting measurable CB reactivity. Polypeptides of 6 or more amino acids show considerable variation in reactivity, ranging from essentially no reaction to as much as 4 times the reaction found for the larger proteins. These variations can be explained by the composition of the polypeptides, with greater reactivity associated with those polymers containing an abundance of basic and hydrophobic amino acids (Righetti \& Chillemi 1978). These findings are consistent with and extend those of Sedmak \& Grossberg (1977) and Righetti \& Chillemi (1978).

\section{PROTEIN IN NEARSHORE MARINE SEDI- MENTS}

Measurements of protein concentrations of about 100 muddy, surficial sediments of the Gulf of Maine, its associated estuaries, and the Salt River estuary in St. Croix (U.S. Virgin Islands) have yielded values ranging from 0.13 to $2.2 \mathrm{mg}$ protein ( $\mathrm{g}$ sediment) ${ }^{-1}$. The contribution of protein nitrogen $(0.16 \times$ protein $)$ to total nitrogen (measured by Carlo Erba $1106 \mathrm{CHN}$ Analyzer) ranges from 3 to $11 \%$, while protein nitrogen to total hydrolyzable amino acid nitrogen (concentrated $\mathrm{HCl}$ hydrolysis followed by analysis with an amino acid analyzer) ratios vary from 10 to $20 \%$ (L. Mayer \& S. Macko unpubl. data). These results are consistent with the ability of proteolytic enzymes to hydrolyze extracts from soil, as found by Sowden

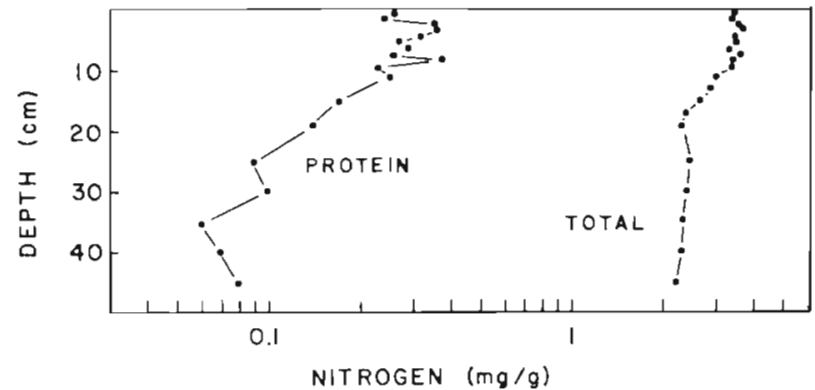

Fig. 2. Concentrations of protein nitrogen and total nitrogen versus depth for a core collected at the mouth of the Sheepscot estuary, Maine

(1970), although the methods by which we and Sowden assessed efficiency of hydrolysis are somewhat different. It is therefore clear that this method measures a small portion of the nitrogen in sediments.

Fig. 2 shows a typical plot of the concentrations of protein nitrogen and total nitrogen as a function of depth, for a site at the mouth of the Sheepscot River estuary, Maine. The relative lability of the fraction of material that our technique measures can be gauged from the fact that protein concentrations decrease with depth in cores much more quickly than total nitrogen. Total hydrolyzable amino acid concentrations in this region are usually quite parallel to total nitrogen (Macko unpubl. data), indicating the greater lability of protein than total amino acids.

We assessed the likely contribution of living biomass to the protein pool by measuring bacterial numbers on a series of surficial sediment samples in an estuaryshelf transect (Table 3). Bacteria were counted by the DAPI method of DeFlaun \& Mayer (1983). Assuming that bacteria contain $1.4 \times 10^{-14} \mathrm{~g}$ carbon cell ${ }^{-1}$, with a $C: N$ ratio of 4 and all of the nitrogen as protein, the bacterial protein made up 0.8 to $3.0 \%$ of the total protein. The data of Schwinghamer (1981) indicate that bacteria generally make up a third or more of the biomass in sediments typical of those in our study area, assuming larger macrofauna are excluded (as is done

Table 3. Bacterial numbers, protein nitrogen and total nitrogen concentrations for a series of surficial sediment samples along an estuarine-shelf transect, Gulf of Maine. The contributions of bacterial nitrogen to protein nitrogen and of protein nitrogen to total nitrogen are calculated according to assumptions described in the text.

\begin{tabular}{|c|c|c|c|c|c|c|}
\hline Station & $\begin{array}{c}\text { Distance } \\
\text { offshore } \\
(\mathrm{km})\end{array}$ & $\begin{array}{l}\text { Bacteria } \\
\left(\text { no. } \mathrm{g}^{-1}\right)\end{array}$ & $\begin{array}{c}\text { Total } \\
\text { nitrogen } \\
\left(\mathrm{mg} \mathrm{g}^{-1}\right)\end{array}$ & $\begin{array}{l}\text { Protein } \\
\text { nitrogen } \\
\left(\mathrm{mg} \mathrm{g}^{-1}\right)\end{array}$ & $\begin{array}{c}\frac{\text { Bacterial nitrogen }}{\text { Protein nitrogen }} \\
(\%)\end{array}$ & $\frac{\text { Protein nitrogen }}{\text { Total nitrogen }}$ \\
\hline 1 & 19.0 & $3.4 \times 10^{8}$ & 2.59 & 0.15 & 0.8 & 5.7 \\
\hline 2 & 11.0 & $1.0 \times 10^{9}$ & 1.87 & 0.12 & 3.0 & 6.4 \\
\hline 3 & 3.1 & $1.2 \times 10^{9}$ & 3.32 & 0.29 & 1.4 & 8.7 \\
\hline 4 & 2.9 & $1.5 \times 10^{9}$ & 2.87 & 0.25 & 2.1 & 8.7 \\
\hline 5 & -1.8 & $1.2 \times 10^{9}$ & 3.80 & 0.30 & $\begin{array}{l}2.1 \\
1.4\end{array}$ & 7.9 \\
\hline 6 & -9.7 & $1.5 \times 10^{9}$ & 3.95 & 0.37 & 1.4 & 9.4 \\
\hline
\end{tabular}


in our protein analysis). Therefore, the total sediment biomass is unlikely to contribute more than about $10 \%$ of the protein measured in these sediments. We conclude that there exist significant amounts of non-living protein in these sediments.

It is also worth noting in these data an expectedly lower contribution of protein nitrogen to total nitrogen in the seaward site relative to the inshore sites. We have observed this trend in a much larger suite of samples taken in the estuaries and on the shelf. This trend is indicative of a relatively higher nutritive value for inshore muds relative to deeper sediments offshore Associated with this trend is a tendency for protein losses downcore to be more extreme at estuarine sites relative to offshore stations.

One of the principal uses for this technique will likely be as an assessment of the nutritional quality of sedimentary organic matter to benthic heterotrophs. Our technique has the advantage of 'seeing' sedimentary protein from the operational perspective of digestibility by enzymes similar to those used by benthic heterotrophs. However, our use of a $0.1 \mathrm{~N} \mathrm{NaOH}$ extraction step, in order to remove maximal protein from the sediment, is harsher and likely far more effective in making protein available to enzymatic attack than the typical benthic animal or bacterium. Our technique may therefore overestimate biologically available protein in sediments. Evidence for this overestimation is provided by the survival of protein measurable by this technique to depths of several tens of $\mathrm{cm}$ into slowly depositing Gulf of Maine sediments. Even closer approximations to a measure of biologically available protein may be attainable by altering the extraction step.

\section{CONCLUSIONS}

(1) An ecologically meaningful measurement of sedimentary protein can be achieved by combining the $C B$ dye reaction, which is sensitive only to larger polypeptides, with an enzymatic digestion step, in order to assess that fraction of polypeptides potentially available to digestion by benthic heterotrophs. The adaptation of the dye-binding method as reported here overcomes problems of protein-protein variability and humic substance interference. Precision of better than $\pm 20 \%$ is typical for surficial sediments. Although tedious, this method offers the closest approximation to a measure of bioavailable, proteinaceous material in complex sedimentary material with which we are familiar

(2) Concentrations of protein in nearshore Gulf of Maine and St. Croix sediments range from 0.1 to $2 \mathrm{mg} \mathrm{g}^{-1}$ These levels account for 10 to $20 \%$ of total hydrolyzable amino acids and 3 to $10 \%$ of total sedimentary nitrogen. Counts of bacterial numbers suggest that biomass makes up less than $10 \%$ of the protein found in these sediments, indicating the presence of non-living protein.

Acknowledgements. We thank L. Watling for his assistance in the collection of samples. This work received partial support from NSF (ISP 8011448), NOAA Sea Grant (R/LRF-45), the Petroleum Research Fund (American Chemical Society), and NOAA Hydrolab (Contribution \#7), and constitutes Contribution \# 15 from the Maine Benthic Oceanography Group.

\section{LITERATURE CITED}

Bearden, J. C. Jr. (1978). Quantitation of submicrogram quantities of protein by an improved protein-dye binding assay. Biochim. biophys Acta 533: 525-529

Bradford, M. M. (1976). A rapid and sensitive method for the quantitation of microgram quantities of protein utilizing the principle of protein-dye binding. Analyt. Biochem. 72 : 248-254

Buchanan, J. B., Longbottom, M. R. (1970). The determination of organic matter in marine muds: the effect of the presence of coal and the routine determination of protein. $J$. exp. mar Biol. Ecol. 5: 158-169

Carter, P. W., Mitterer, R. M. (1978). Amino acid composition of organic matter associated with carbonate and noncarbonate sediments. Geochim. cosmochim. Acta 42: $1231-1238$

D'Elia, C. F., Steudler, P. A., Corwin, N. (1978). Determination of total nitrogen in aqueous samples using persulfate digestion. Limnol. Oceanogr. 23: 760-764

DeFlaun, M. F. Mayer, L. M. (1983). Relationships between bacteria and grain surfaces in intertidal sediments. Limnol. Oceanogr. 28: 873-881

Es, F. B. van (1982). Community metabolism of intertidal flats in the Ems-Dollard estuary. Mar. Biol. 66: 95-108

Greenfield, L. J., Hamilton, R. D., Weiner, C. (1970). Nondestructive determination of protein, total amino acids, and ammonia in marine sediments. Bull. mar. Sci. 20: 289-304

Hatcher, P. G. (1978). The organic geochemistry of Mangrove Lake, Bermuda. NOAA Professional Paper 10, p. 1-92

Hedges, J. I., Stern, J. H. (1984). Carbon and nitrogen determinations of carbonate-containing solids. Limnol. Oceanogr 29: 657-663

Mayer, L. M., Rahaim, P. T., Guerin, W., Macko, S. A., Watling, L. Anderson. F. E. (1985). Biological and granulometric controls on sedimentary organic matter of an intertidal mudflat. Estuar. coast. Shelf Sci. 20: 491-503

Meyer-Reil, L.-A. (1983). Benthic response to sedimentation events during autumn to spring at a shallow water station in the Western Kiel Bight. II. Analysis of benthic bacterial populations. Mar Biol. 77.247-256

Mills, G. L., Quinn, J. G. (1978). Determination of organic carbon in marine sediments by persulfate oxidation Chem. Geol. 25: 155-162

Mopper, K. (1977). Sugars and uronic acids in sediment and water from the Black Sea and North Sea with emphasis on analytical techniques. Mar. Chem. 5: 585-603

O'Haver, T C. (1976). Analytical considerations. In. Winefordner, J. D. (ed.) Trace analysis: Spectroscopic methods for elements. John Wiley and Sons, New York, p. 15-62 
Pollard, H. B., Menard, R., Brandt, H. A., Pazoles, C. J., Creutz, C. E., Ramu, A. (1978). Application of Bradford's protein assay to adrenal gland subcellular fractions. Analyt. Biochem. 86: 761-763

Read, S. M., Northcote, D. H. (1981). Minimization of variation in the response to different proteins of the Coomassie blue $G$ dye-binding assay for protein. Analyt. Biochem. 116: 53-64

Rice, D. L. (1982). The detritus nitrogen problem: New observations and perspectives from organic geochemistry. Mar. Ecol. Prog. Ser. 9: 153-162

Righetti, P. G., Chillemi, F. (1978). Isoelectric focusing of peptides. J. Chromatogr. 157 243-251

Schwinghamer, P. (1981). Characteristic size distributions of integral benthic communities. Can. J. Fish. Aquat. Sci. 38: $1255-1263$
Sedmak, J. J., Grossberg, S. E. (1977). A rapid, sensitive, and versatile assay for protein using Coomassie Blue G250 Analyt. Biochem. 79: 544-552

Setchell, F. W. (1981). Particulate protein measurement in oceanographic samples by dye binding. Mar. Chem. 10 301-313

Simon, B. M., Jones, J. G. (1983). Gas chromatographic determination of total amino acids and protein in sediments using the ninhydrin- $\mathrm{CO}_{2}$ reaction. Hydrobiologia 101. 189-194

Sowden, F. J. (1970). Action of proteolytic enzymes on soil organic matter. Can. J. Soil Sci. 50: 233-241

Tenore, K. R. (1983). Organic nitrogen and caloric content of detritus III. Effect on growth of deposit-feeding polychaete, Capitella capitata. Estuar. coast. Shelf Sci. 17 $733-742$

This article was presented by Professor K. R. Tenore; it was accepted for printing on March 3, 1986 